\title{
Use and delivery of blood platelet to the national blood transfusion Center (NBTC) of Cote d'Ivoire
}

\author{
Sekongo Y. M. ${ }^{1}$, Konan S. ${ }^{1}$, Kouamenan S. ${ }^{1}$, Tchimou J. ${ }^{1}$, Tiembre I. ${ }^{2}$, Abisse A. ${ }^{3}$, Tolo A. D. ${ }^{3}$, \\ Siransy-Bogui L. ${ }^{1}$, Yeo N. ${ }^{1}$, Konate S. ${ }^{1}$ \\ ${ }^{1}$ NationalCenter for Blood Transfusion (CNTS), BP V15 Km4, Boulevard de Marseille, Abidjan Côte d'Ivoire \\ ${ }^{2}$ National Institute for Public Hygiene(INHP), Abidjan Côte d'Ivoire \\ ${ }^{3}$ Department of ClinicalHematology, YopougonTeachingHospital, Abidjan Côte d'Ivoire
}

\section{Email address: \\ sekyass@yahoo.fr (Sekongo Y. M.)}

\section{To cite this article:}

Sekongo Y. M., Konan S., Kouamenan S., Tchimou J., Tiembre I., Abisse A., Tolo A. D., Siransy-Bogui L., Yeo N., Konate S.. Use and Delivery of Blood Platelet to the National Blood Transfusion Center (NBTC) of Cote d'Ivoire. European Journal of Preventive Medicine. Vol. 1, No. 3, 2014, pp. 79-81.doi: 10.11648/j.ejpm.20130103.15

\begin{abstract}
Objectives: To know the use of blood platelets and their delivery by the National Blood Transfusion Center of Côte d'Ivoire; describe the socio-demographic characteristics of patients receiving transfusion of blood platelets; specify the platelets order history(old or new command); to assess the delivery of platelets by the National blood Transfusion Center (NBTC) and then specify the group of patients requiring blood transfusion of platelets at the National blood Transfusion Center of Côte d'Ivoire. This was a descriptive cross-sectional study that concerned the period from 01 November to 30 November 2012. It was a comprehensive study that involved 36 controls platelet registered to the NBTC during the defined period. Of the 36 orders of platelets retained the age group 0-10 years was the most frequent with $33.3 \%$ of cases. There were $63.9 \%$ men and $32.6 \%$ women. Pupils and students predominated with $30.5 \%$ of cases. Most orders platelets came equally to Cocody Teaching Hospital and Yopougon Teaching Hospital with $30.5 \%$. Services leading orders platelets were hematology services with $22.2 \%$ and pediatrics with $16,6 \%$.In $33.3 \%$ of cases, patients requiring platelet transfusion lived in Yopougon. Among orders platelets, news represented $58.3 \%$. The delivery of blood platelets by the National Blood Transfusion Center was three days or more in most cases with $44.4 \%$ and patients requiring platelet transfusion were in $38.9 \%$ of cases of group $\mathrm{O}$ Rh positive. At the end of our study, we can remember that most orders platelets come from hematology and pediatrics services of CocodyTeachingHospital and YopougonTeachingHospital. These orders are made primarily of platelets for patients of group $\mathrm{O} \mathrm{Rh}$ positive and issued by theNBTCwithin 3 days or more in most cases.
\end{abstract}

Keywords: Plateletblood- Delivery - NBTC

\section{Introduction}

Platelets are blood cells involved in hemostasis [1]. In transfusion, they are obtained either by separation of blood components from a whole blood donation or by apheresis $[2 ; 3]$. Indications are multidisciplinary in medicine. Made of their short lifespan ( 3 to 5 days), and their aggregation power $[4 ; 5]$, platelets are not systematically produced by the NBTC of Côte d'Ivoire insufficient as red blood cells or plasma. Production obeys in most cases to prior orders whose delivery and satisfaction are function of the amount of blood and the number of available donors, whereas the control of blood platelets is most often done in extreme emergencies situations or in order to prevent the risk of bleeding or to treat coagulopathies $[2 ; 6 ; 7]$.

The National Blood Transfusion Center (NBTC) of Abidjan is located in the town of Treichville. This is the only blood structure in Côte d'Ivoire ability to collect, process and deliver the blood platelets.

To improve the quality of service on the issuing of platelets, we conducted this study aimed to clarify the characteristics of prescribing them and their delivery by the NBTC.

\section{Methodology}

This was a descriptive cross-sectional study from 01 to 
30 November 2012. It involved 36 controls platelet on 39 registered to the NBTC of Abidjan during the defined period.

The orders of platelets cancel before the calling of the NBTC for delivery and all those honored at the command were not included.

Data collection was done prospectively using a questionnaire that was filled from the registry platelet of the NBTC of Abidjan. The following parameters were studied: age, sex, occupation, marital status, residence, structures and health services applicants, order history, delivery time and blood groups. The processing and data analys were performed on Excel 2010.

\section{Results}

\subsection{Socio-Demographic Profile}

Table 1.Distribution of platelets orders according to age, sex and occupation

\begin{tabular}{|c|c|c|c|}
\hline parameter & & Number(n=36) & percentage \\
\hline \multicolumn{4}{|l|}{ Age (year) } \\
\hline & {$[0-10]$} & 12 & 33,3 \\
\hline & {$[11-20]$} & 8 & 22,2 \\
\hline & {$[21-30]$} & 3 & 8,3 \\
\hline & [31-40] & 6 & 16,7 \\
\hline & {$[41-50]$} & 2 & 5,6 \\
\hline & [51-60] & 5 & 13,9 \\
\hline \multicolumn{4}{|l|}{$\operatorname{sex}$} \\
\hline & male & 23 & 63,9 \\
\hline & female & 13 & 36,1 \\
\hline \multicolumn{4}{|l|}{ profession } \\
\hline & Pupils / students & 11 & 30,6 \\
\hline & Civil servant & 6 & 16,7 \\
\hline & Tertiary sector & 6 & 16,7 \\
\hline & Unemployed & 8 & 22,2 \\
\hline & Unspecified & 5 & 13,9 \\
\hline \multicolumn{4}{|l|}{ Residence } \\
\hline & Cocody & 4 & 11,1 \\
\hline & Treichville & 2 & 5,6 \\
\hline & Port-Bouet & 2 & 5,6 \\
\hline & Adjame & 1 & 2,8 \\
\hline & Yopougon & 13 & 36,1 \\
\hline & Koumassi & 2 & 5,6 \\
\hline & Non précisé & 12 & 33,3 \\
\hline
\end{tabular}

The age of 0-10 year olds was the most frequent with $33.3 \%$ of blood platelets orders followed by the age group of 11 to 20 years with $22.3 \%$.

There were $63.9 \%$ male and $36.2 \%$ female.

Pupils and studens represented $30.5 \%$ of case.
Approximately 33.3\% lived in Yopougon against 33.3\% who were unable to have their residence specified.

Table 2. Distribution of platelets orders according to the hospital and the health service

\begin{tabular}{llll}
\hline Parameter & & Number(n=36) & pourcentage \\
\hline Hospital & & & \\
& CocodyTeachingHospital & 11 & 30,6 \\
& TreichvilleTeachingHosp & 8 & 22,2 \\
& ital & & 30,6 \\
& YopougonTeachingHosp & 11 & 16,7 \\
& ital & 6 & \\
& clinique & & 13,9 \\
Service & & 5 & 5,6 \\
& Medecine & 2 & 16,7 \\
& chirurgy & 6 & 5,6 \\
& pediatry & 2 & 22,2 \\
& Gynecology & 8 & 8,3 \\
& Hematology & 3 & 8,3 \\
& Reanimation & 3 & 8,3 \\
& Pneumology & 3 & 11,1 \\
\hline
\end{tabular}

CocodyTeachingHospitalandYopougonTeachingHospital come equally with $30.6 \%$.

The hematology department led with $22.2 \%$ followed by the pediatric service with $16.7 \%$ of the platelets orders.

Table 3. Distribution of platelets orders according to historical, delivery and blood group

\begin{tabular}{llll}
\hline Parameter & & Number(n=36) & pourcentage \\
\hline Platelets history & & & \\
& news & 21 & 58,3 \\
Delivery time & Old & 15 & 41,7 \\
& & & \\
& One day & 6 & 16,7 \\
& Two days & 11 & 30,6 \\
& Three days and more & 16 & 44,4 \\
& unspecified & 3 & 8,3 \\
Blood group & & 11 & \\
& A+ & 6 & 30,6 \\
& B+ & 1 & 16,7 \\
& AB+ & 14 & 2,8 \\
& O+ & 0 & 38,9 \\
& A- & 2 & 0 \\
& B- & 0 & 5,6 \\
& AB- & 2 & 0 \\
& O- & & 5,6 \\
\hline
\end{tabular}

In $58.3 \%$ of cases, there was a new order.

In $44.4 \%$ of cases, platelets were delivered in three days and more followed; those delivered within two days with $30.6 \%$ of cases.

In $38.9 \%$ of cases, platelets orders were placed for patients of $\mathrm{O}$ Rh positive group. 


\section{Comments}

Platelets orders affect all age groups with a minimum of 2 months and a maximum of 60 years. The most common age group is that between 0 and 10 years, this could be explained by the fact that most applicant services are pediatric and hematology with a strong cohort of children. This was reported in the Activity Report of the NBTC of Côte d'Ivoire 2010[8].

According to Mauvieux, some acute auto immune thrombocytopenia, more frequent in children, can complicate a viral infection such as measles, rubella [9].

Most orders platelets was destined to students in $30.5 \%$ of cases. This could be explained by the fact that although these are not part of the fringe occupations exposed to carcinogenic risks could have been exposed at some point to one of the risk factors. These were thrombocytopenia secondary to malignancies or chemotherapy for hematology services and parasitic (malaria) and sepsis in the context of pediatric services $[10 ; 11 ; 12]$.

In our study, we observed a male predominance with $63.9 \%$ of cases. However according to the literature, thrombocytopenia are independent of sex but may vary during pregnancy [9].

In $33.3 \%$ of cases, patients with past orders platelets resided in the municipality of Yopougon .

At equal value, the hematology service of Yopougon Teaching Hospital and the pediatric service of Cocody Teaching Hospital were found in $30.5 \%$ of cases. This could be explained by the fact that these services are those who are in charge of hematological malignancies deseases and mostly parasitic and septicemia in children.

New orders platelet predominated in $58.3 \%$. This could be explained by the fact that controls blood platelets become more frequent as the need for the provision of these patients as soon as possible by the NBTC. It also draws attention to a likely increase in the incidence of malignancies deseases in Côte d' Ivoire. Delivery in $75 \%$ of cases was more than two days (more than forty-eight hours) This could be explained by a delay in the biological characterization of the donation by the fact that we do not produce platelets by apheresis and finally because of the limited number of regular blood donors.

In $38.9 \%$ of cases, the blood group of patients requiring transfusion of platelets was $\mathrm{O} \mathrm{Rh}$ positive. This result corroborate those of Dulai and al [13] in a study conducted in 1985 at the National Institute of Public Health and the activities reports of NBTC of Côte d'Ivoire [14]which revealed that $48 \%$ of Ivorian are $\mathrm{O}$ positive.

It would be interesting for the NBTC anticipate the preparation of all groups of platelets with emphasis on the most common groups to meet orders in handle emergencies.

\section{Conclusion}

At the end of our study, we found that most orders platelets were made in emergencies, to children, primarily pediatric wards and hematology of Cocody Teaching Hospital and Yopougon Teaching Hospital, all located to more twenty kilometers from Abidjan NBTC. Unfortunately these commands were honored in most cases beyond forty-eighth ours, which could jeopardize the prognosis of these patients. It is therefore important that steps be taken by the NBTC of Côte d'Ivoire for the systematic production of platelets insufficient quantity.

\section{References}

[1] Rene T: Globules rouges, plaquettes, plasma...Quel role jouent-ilsdansl'organisme. www.dondusang.net/lescomposants-du-sang.

[2] Agence Française de sécurité. Transfusion de plaquettes sanguines: Produits, indications. P10. DisponibleSurwww.hemovigilance-cncrh.fr.

[3] Rene T: Informations-sur-le-sang. www.donnersonsang.org

[4] Sante-médecine. www.Commentcamarche.net/ Numération des plaquettes.

[5] Wikipedia-Trombocyte. Disponible sur fr. wikipedia.org/Wiki/ Thrombocyte.

[6] SocietéFrançaise de vigilance. Transfusionssanguines : Applications cliniques. www.urgencehsj.ca/Librairies.

[7] PNDS surpurpurathrombopeniquesimmunologiqueswww. Has-sante.fr/ .../ald-n-é-pnds-sur-purpura-thrombopénique.

[8] Centre National de Transfusion Sanguine: Rapport d'activités 2010, Abidjan Côte d'Ivoire.

[9] Mauvieux L: Trombopenies: Orientation diagnostique devant une thrombopénie. Disponible sur medidacte.timone.univ- mrs.fr/webcours/comité.

[10] Actualités. Quelsrisquesprofessionnelsexposent aux hémopathiesmalignes.Disponiblesurwww. Atoutsante.com, Actualités.

[11] Wikipediathrombopenie.fr.wikipedia.org/wiki/Thrombopénie.

[12] Wikipedia-Hematologie.fr.wikipédia.org/wiki/Hématologie.

[13] C.Dulai, J L Rey, C Troley. Répartitionethnique des groups sanguins en Côte d'Ivoire. Disponiblesur www.documentation.ird.fr/hor/fdi:31336

[14] Centre National de Transfusion Sanguine: Rapport d'activité 2011, Abidjan Côte d'ivoire 